\title{
PENGARUH KEMAJUAN TEKNOLOGI INFORMASI DAN PENGETAHUAN INVESTASI TERHADAP MINAT INVESTASI GENERASI MILENIAL DI PASAR MODAL
}

\author{
Andi Kusuma Negara ${ }^{1}$, Hendra Galuh Febrianto ${ }^{2}$ \\ 1,2 Fakultas Ekonomi Dan Bisnis Universitas Muhammadiyah Tangerang
}

Diterima 29-6-2020 /Disetujui 7-8-2020

\begin{abstract}
The number of millennial or forces born between 1981-2000 according to the 2017 National Socioeconomic Survey (Susenas) counts 88 million people or 33.75 per cent of Indonesia's population (BPS). PT Indonesian Central Securities Depository (KSEI) noted that young people or millennial generation still count the number of investors in the Indonesian capital market. Throughout 2018 the number of young investors reaching 21-30 years won 39.72\% of the number of investors. Therefore BEI participated in using the Indonesian Central Securities Depository (KSEI) \& securities companies began to hold a variety of lessons ranging from talk shows, seminars to workshops \& capital market schools (SPM) information technology and investment knowledge. This research method is a causal relationship research with quantitative data with SPSS tools. contributing to this research were students of the faculty of economics and business at the University of Muhammadiyah Tangerang with a sample of 92 respondents. the results of this study indicate the fact that the development of information technology is significant to the investment interests of millennial. While investment knowledge has a positive and significant impact on investment interests in millennial.
\end{abstract}

Keywords: Information Technology, Investment Knowledge, Investment Interest, Capital Market

\begin{abstract}
ABSTRAK
Jumlah para milenial atau angkatan yang lahir antara tahun 1981-2000 menurut Susenas (Survei Sosial Ekonomi Nasional) tahun 2017 berjumlah 88 juta jiwa atau 33,75 persen dari jumlah penduduk Indonesia (BPS).PT Kustodian Sentral Efek Indonesia (KSEI) mencatat anak muda atau generasi milenial masih mendominasi jumlah investor di pasar modal Indonesia. Sepanjang 2018 jumlah investor muda berusia 21-30 tahun mendominasi 39,72\% jumlah investor.oleh karena itu BEI bekerjasama menggunakan Kustodian Sentral Efek Indonesia (KSEI) \& perusahaan sekuritas mulai menyelenggarakan aneka macam bentuk pembelajaran mulai menurut talkshow, seminar sampai workshop \& Sekolah Pasar Modal (SPM)Penelitian ini bertujuan untuk mengetahui minat generasi milenial dalam berinvestasi dipasar modal dipengaruhi oleh teknologi informasi dan pengetahuan investasi. metode penelitian ini penelitian hubungan kausal dengan data kuantitatif dengan alat bantu SPSS. populasi pada penelitian ini yaitu mahasiswa fakultas ekonomi dan bisnis Universitas muhammadiyah tangerang dengan sampel sebanyak 92 responden. hasil penelitian ini menunjukan bahwa kemajuan teknologi informasi berpengaruh signifikan terhadap minat investasi generasi milenial. sedangkan pengetahuan investasi berpengaruh positif dan signifikan terhadap minat investasi generasi milenial.
\end{abstract}

Kata Kunci : Teknologi Informasi, Pengetahuan Investasi, Minat Investasi, Pasar Modal

\footnotetext{
*Korespondensi Penulis:

E-mail: hgf.4646@gmail.com ${ }^{1}$
} 
PENDAHULUAN

Jumlah investor pada tahun 2018 di pasar modal mengalami peningkatan dan Bursa Efek Indonesia (BEI) menyebut, ratarata dari total investor tersebut berasal dari generasi milenial. Jumlah para milenial atau angkatan yang lahir antara tahun 1981-2000 menurut Susenas (Survei Sosial Ekonomi Nasional) tahun 2017 berjumlah 88 juta jiwa atau 33,75 persen dari jumlah penduduk Indonesia (BPS). PT Kustodian Sentral Efek Indonesia (KSEI) mencatat anak muda atau generasi milenial masih mendominasi jumlah investor di pasar modal Indonesia. Sepanjang 2018 jumlah investor muda berusia 21-30 tahun mendominasi 39,72\% jumlah investor. Adapun KSEI mencatat data Single Investor Identification (SID) per 26 Desember 2018, jumlah investor di Pasar Modal Indonesia mencapai 1,6 juta. Angka ini meningkat $44,06 \%$ dibandingkan jumlah investor diperiode yang sama di 2017 sebesar 1,1 juta. Jumlah investor tersebut terkonsolidasi, yang terdiri dari investor Saham, Surat Utang, Reksa Dana, Surat Berharga (SBSN) dan Efek lain yang tercatat di KSEI. Hal yang menggembirakan, investor usia muda di bawah 30 tahun atau milenial mencapai $39,72 \%$, naik dibandingkan tahun lalu sekitar 28\% (dari total investor 1,1 juta di 2017), (okezone.com). jumlah itu masih kurang dari potensi generasi milenial yang ada.

Oleh karena itu pasar modal dengan pertimbangan tertentu. Bursa Efek Indonesia (BEI), Lembaga Kliring dan Penjaminan (KPEI) dan PT Kustodian Sentral Efek Indonesia (KSEI) sebagai fasilitator pasar modal Indonesia berusaha agar jumlah investor Indonesia meningkat dengan berbagai cara.

$$
\text { Dalam rangka menaikkan }
$$

pengetahuan mengenai dunia investasi di Indonesia, maka BEI bekerjasama menggunakan Kustodian Sentral Efek Indonesia (KSEI) \& perusahaan sekuritas mulai menyelenggarakan aneka macam bentuk pembelajaran mulai menurut talkshow, seminar sampai workshop \& Sekolah Pasar Modal (SPM) (Merawati \& Putra, 2015). Mahasiswa adalah generasi milenial yang menjadi calon investor belia mulai dilirik karena pada masa depan akan dapat berkontribusi aktif bagi dunia investasi seperti pasar modal, upaya lain dalam peningkatan pengetahuan mahasiswa antara lain melalui pembelajaran mata kuliah bank \& lembaga keuangan, dan mata kuliah pasar modal.

Mahasiswa merupakan salah satu individu yang potensial untuk melakukan investasi. Berbekal pembelajaran yang didapat selama perkuliahan. Mahasiswa dapat menerapkan teori yang telah didapatkannya selama perkuliahan dengan riil berupa praktek investasi.

Pasar modal merupakan alternatif bagi mahasiswa atau investor untuk berinvestasi baik dalam jangka pendek maupun jangka panjang. Saham ialah salah satu produk keuangan pasar modal yang diperjual belikan dan yang paling populer. Saham merupakan surat berharga sebagai tanda bukti kepemilikan atau penyertaan dari perorangan maupun instansi dalam suatu perusahaan (Anoraga, 2001). Sebelum melakukan investasi pada satu instrumen investasi, Investor mempelajari segala hal yang berhubungan dengan investasi. Para investor menyadari bahwa investasi dapat menguntungkan dimasa depan.

Pasar modal adalah tempat di mana investor bertemu dengan emiten yang akan menawarkan dan meminta sekuritas. Ketika seseorang ingin dirinya sebagai investor potensial, hal yang perlu dipertimbangkan adalah pengetahuan yang ia miliki tentang pasar modal, jadi ia harus belajar dengan benar seperti apa pasar modal itu. Jadi dengan stok yang memadai ini, calon investor dapat menarik diri dari praktik konotasi negatif seperti perjudian, penipuan, dan menyebabkan kerugian besar bagi diri mereka sendiri. Selain pengetahuan yang luas terkait dengan pasar modal, calon investor harus memiliki keahlian khusus dalam memeriksa dan memahami kondisi pasar sehingga ia dapat mengetahui keputusan apa yang harus dipilih agar tidak menderita kerugian (Halim, 2005, p. 4). Instrumen di pasar modal harus sangat dipahami sehingga kerugian dalam bayangan investor akan hilang dengan saham yang mereka miliki. 
Pada biasanya orang berinvestasi karena ingin mendapatkan return yang cukup tinggi atau sinkron dengan harapannya. Return bisa diperoleh menurut deviden atau capital gain, pada sisi lain investasi juga mengandung risiko. Risiko tersebut bisa berasal menurut internal perusahaan maupun eksternal perusahaan Investasi pada awalnya dilakukan sang kalangan pengusaha, pebisnis, dan orangorang yang berkepentingan melakukan investasi.

Setiap investor yang berinvestasi dalam saham memiliki tujuan yang sama, yaitu untuk memperoleh capital gain, yaitu perbedaan positif antara harga jual dan harga beli saham dan dividen tunai yang diterima dari penerbit, karena perusahaan menghasilkan untung Terlalu. Jika harga jual lebih rendah dari harga pembelian saham, investor akan menderita kerugian (capital loss). Selain memiliki tujuan yang sama, investor juga memiliki tujuan investasi yang berbeda, yaitu laba jangka pendek dan laba jangka panjang.

Perkembangan teknologi dewasa ini memiliki pengaruh yang besar terhadap kemajuan ekonomi suatu negara dan mendorong sektor bisnis menjadi lebih efisien dan efektif dalam menjalankan operasi usaha untuk mencapai hasil yang maksimal. Sektor pasar modal dan keuangan memang menjadi salah satu tolak ukur perekonomian di suatu negara dimana terdaftar ribuan perusahaan yang menjualbelikan sahamnya di pasar sekunder atau bursa saham. Kecepatan dan ketepatan dalam transaksi di lantai bursa sangatlah dibutuhkan sehingga investor, broker, trader dan institusi yang terkait dapat dengan cepat menganalisis dan mengambil keputusan. Sejalan dengan perkembangan teknologi informasi dan internet, transaksi pasar modal kini semakin banyak digemari oleh investor milenial dengan adanya fasilitas online trading yang diberikan oleh perusahaan sekuritas atau broker. Fasilitas online trading ini memudahkan para investor untuk dapat bertransaksi dimana pun dan kapan pun menggunakan perangkat yang dapat mengakses internet sehingga memudahkan investor dalam pengambilan keputusan. Selain itu para investor juga dapat mengakses laporan keuangan, tren saham, membaca berita dan menilai return dan risiko saham perusahaan dengan menggunakan sistem online trading.

Perkembangan teknologi saat ini memiliki dampak besar pada perkembangan ekonomi suatu negara dan mendorong sektor bisnis untuk melakukan bisnis secara lebih efisien untuk mencapai hasil yang maksimal. Sektor pasar modal dan keuangan memang menjadi salah satu tolok ukur ekonomi negara, dan ribuan perusahaan di negara itu menjual saham mereka di pasar sekunder atau pasar saham. Diperlukan kecepatan dan akurasi perdagangan di lantai perdagangan sehingga investor, pialang, pedagang, dan lembaga terkait dapat dengan cepat menganalisis dan membuat keputusan. Sayangnya, kemajuan teknologi Indonesia belum disertai dengan pemahaman atau pemahaman tentang dunia investasi. Menurut survei "Literasi dan Integrasi Keuangan Nasional" 2016 yang dilakukan oleh Administrasi Layanan Keuangan (OJK) Kementerian Pendidikan dan Departemen Integrasi Keuangan dan Perlindungan Konsumen, diyakini bahwa masyarakat kurang memahami pasar modal. Indeks literasi keuangan pasar modal 2016 adalah 4,4\%, konvensional 4,4\%, dan doktrin Islam $0,02 \%$. Menurut data, ini berarti bahwa pemahaman masyarakat tentang pasar modal masih relatif rendah.

Kemajuan teknologi di Indonesia sayangnya belum diiringi oleh tingkat literasi atau pemahaman terhadap dunia investasi. Berdasarkan Survei Nasional Literasi dan Inklusi Keuangan 2016 yang dilakukan oleh Departemen Literasi dan Inklusi Keuangan Departemen Edukasi dan Perlindungan Konsumen Otoritas Jasa Keuangan (OJK), tingkat pemahaman masyarakat terhadap pasar modal dinilai masih kurang. Indeks literasi keuangan tahun 2016 pasar modal sebesar 4,4\% komposit, 4,4\% konvensional, dan 0,02\% syariah. Sesuai data tersebut berarti pengetahuan masyarakat terhadap pasar modal relative masih rendah. Persentase tersebut merupakan yang paling kecil dari indeks literasi keuangan OJK lainnya seperti, perbankan, perasuransian, dana 
pensiun, lembaga pembiayaan, dan pegadaian. Hal tersebut menandakan bahwa masyarakat Indonesia banyak yang belum paham dunia pasar modal serta belum menjadikan saham dan reksadana sebagai pilihan utama dalam berinvestasi.

Dengan semakin mudahnya akses terhadap informasi pasar modal, diharapkan akan memunculkan minat investor atau calon investor untuk berinvestasi. Kemudahan tersebut diharapkan akan berdampak langsung pada peningkatan minat berinvestasi saham masyarakat luas khususnya mahasiswa sebagai investor pemula yang bisa dibilang kalangan sadar teknologi. Kedekatan kalangan muda dengan teknologi dapat memudahkan mereka sebagai user dari online trading system.

Salah satu faktor yang dapat memicu minat seseorang khususnya mahasiswa untuk berinvestasi antara lain kemudahan dalam melakukan investasi, baik dari segi akses informasi maupun biaya yang harus dikeluarkan untuk memulaiinvestasi tersebut. Hal ini menjadi sangat penting bagi investor terutama investor pemula khususnya mahasiswa dalam memulai investasi. Sebagian besar mahasiswa belum berpenghasilan dan dari segi finansial belum mampu untuk berinvestasi serta menganggap bahwa berinvestasi adalah mahal. Terlihat jelas hambatan yang tampak memengaruhi laju pertumbuhan investasi yaitu mahalnya biaya untuk memulai transaksi investasi khususnya bagi mahasiswa sebagai calon investor. Untuk itu, banyak perusahaan sekuritas sudah mulai berusaha memberikan program-program promosi untuk memudahkan masyarakat berinvestasi dengan menurunkan jumlah deposit minimum untuk pembukaan rekening yang akan digunakan dalam bertransaksi (Wulandari, 2017). Melalui programprogram tersebut, diharapkan mampu memicu minat calon investor untuk ikut berinvestasi.

Selain faktor tersebut ada faktor lain yang tidak bisa dipungkiri akan mempengaruhi minat berinvestasi yaitu merupakan pengetahuan mengenai investasi itu sendiri dan teknologi informasi. tidak terkecuali pada generasi milenial dalam hal ini mahasiswa Universitas Muhammadiyah tangerang,

(M. C. J. Van Rooij et al., 2011) menganalisis hasil survey terhadap rumah tangga di Belanda dalam penelitiannya yang berjudul "Financial literacy and retirement planning in theNetherlands". Mereka menemukan bahwa orang-orang yangmemiliki pengetahuan tentang keuangan cenderung menggunakan dananya untuk merencanakan pada saatpensiun. (M. van Rooij et al., 2011) dalam penelitiannya yang berjudul "Financial literacy and stock market participation"menemukan bahwa mereka yang memiliki pemahaman ataupengetahuan tentang keuangan memungkinan untukberinvestasi pada saham. Penemuan tersebut mendapat dukungan dari hasil penelitian oleh (Khotimah et al., 2011)dimana pengetahuan berpengaruh terhadap minat investasi. Apabila pengetahuan seseorang tersebut memadai, makaseseorang tersebut terdorong untuk berinvestasi.

Berbeda dengan hasil (Malik, 2017) yang menemukanbahwa pengetahuan tidak berpengaruh terhadap minatinvestasi. Hal tersebut disebabkan karena kurangnyapengetahuan para investor terhadap saham syariah sehinggakurang berminat investasi pada saham syariah. Hasilpenelitian tersebut mendapat dukungan dari hasil penelitianoleh (Nisa \& Zulaika, 2017) yang menemukan bahwamateri tentang investasi yang telah diberikan tidak lagidipertimbangkan bagi para mahasiswa untuk dapat menjadiseorang investor.

$$
\text { Walaupun minat investasi }
$$

mahasiswa cukup tinggi terutama saat di awal pembelajaran, namun tidak sedikit dari mahasiswa yang mengurungkan niatnya ketika teori yang dipelajari dibangku kuliah di praktekan di dunia nyata, ada banyak faktor yang mempengaruhi mengapa hal tersebut terjadi, diantaranya adalah minimnya sisa uang saku yang bisa digunakan untuk diinvestasikan, kurangnya waktu untuk melakukan dan mengawasi transaksi, serta edukasi investasi yang masih terbatas. Apalagi semakin banyaknya dari kalangan masyarakat terutama pebisnis 
maupun mahasiswa lebih berminat berinvestasi di pasar modal. Namun masih banyak kendala yang harus dihadapi dalam investasi ini terutama bagi para investor pemula jika mereka tidak memahami dengan benar tata cara berinvestasi atau risiko apa yang akan dihadapi bagi investor. Melihat hal tersebut maka penulis tertarik untuk melakukan penelitian dengan mengangkat judul "Pengaruh Kemajuan Teknologi Informasi Dan Pengetahuan Investasi Terhadap Minat Investasi Generasi Milenial Di Pasar Modal"

Berdasarkan uraian dari latar belakang tersebut, maka yang menjadi pokok permasalahan pada penelitian ini adalah:

1. Apakah kemajuan teknologi berpengaruh terhadap minat berinvestasi?

2. Apakah pengetahuan pasar modal berpengaruh terhadap minat berinvestasi?

Penelitian ini diharapkan dapat memperluas pengetahuan dan berkontribusi pada pengembangan pengetahuan, terutama di bidang manajemen keuangan terkait dengan investasi dan pasar modal. Dan dapat digunakan sebagai referensi bagi peneliti lain. Selain itu, studi ini diharapkan menjadi bahan evaluasi untuk pasar modal dan lembaga ketiga untuk menganalisis pengembangan manfaat investasi pembangkit listrik, yang dapat mempromosikan dan memfasilitasi investor muda untuk melakukan lebih banyak investasi di pasar modal.

\section{KAJIAN PUSTAKA DAN PENGEMBANGAN HIPOTESIS} Teori Tindakan Beralasan (Theory of Reasoned Action) dan Teori Perilaku Berencana (Theory of Planned Behavior). Theory of Reasoned Action menjelaskan, bahwa perilaku seseorang ditentukan oleh suatu intensi yang merupakan fungsi dan tingkah laku terhadap perilaku norma subyektif. Intensi ini ditentukan oleh tiga hal, yaitu tingkah laku, norma subyektif dan pengendalian perilaku. Theory of Planned Behavior yang merupakan perluasan dari Theory of Reasoned Action. Theory of Planned Behavior didasarkan pada asumsi manusia sebagai mahluk rasional dan menggunakan informasi-informasi yang diperoleh secara sistematis. Orang memikirkan implikasi dari tindakan mereka sebelum mereka memutuskan untuk melakukan atau tidak melakukan perilaku tertentu. Theory of Planned Behavior menyatakan, poin utama yang mampu digunakan untuk memprediksi perilaku adalah intensi tingkah laku (Ajzen, 1991).

Tandio \& Widanaputra (2016) mengatakan bahwa pertimbangan seorang calon investor untuk berinvestasi itu timbul karena adanya kesadaran atau keyakinan individu untuk bertindak. Dengan adanya keinginan atau niat dari calon investor untuk melakukan investasi, maka seseorang akan cenderung melakukan berbagai cara untuk mewujudkan keinginannya tersebut diantaranya dengan mempelajari ilmu yang berkaitan dengan dunia investasi, mengikuti pelatihan - pelatihan tentang pasar modal, dll. Dengan begitu apa yang inginkan akan dapat terwujud.

\section{Pasar Modal}

Pasar modal berdasarkan UndangUndang Pasar Modal (UUPM) no.8 tahun 1995 Pasal 1 Nomor 13 menjelaskan, pasar modal adalah kegiatan yang bersangkutan dengan penawaran umum dan perdagangan efek, perusahaan publik yang berkaitan dengan efek yang diterbitkannya, serta lembaga dan profesi yang berkaitan dengan efek.

Pasar modal dinamakan tempat bertemunya pihak penjual efek secara transparan dengan pihak pembeli efek yang bertemunya tidak secara langsung(Munirah Ira et al., 2012). Pada umumnya pasar modal merupakan sistem keuangan yang ada di Indonesia sebagai sistem yang sangat terorganisir. Hal ini disebabkan oleh dalam pasar modal terdiri beberapa perantara yang mampu menyambungkan lembaga-lembaga keuangan, antara lain bank konvensional yang merupakan bank komersial, serta dibutuhkannya surat berharga baik kepemilikan atau surat tanda utang yang beredar.Menurut (Darmadji \& Fakhruddin, 2012 , p. 1) Manfaat keberadaan pasar modal di Indonesia yaitu:

a) Pengalokasian sumber dana yang sangat optimal dalam melakukan 
penyediaan pinjaman atau pembiayaan dalam jangka waktu yang relatif panjang sehingga bagi keadaan dunia usaha akan sangat membantu.

b) Upaya yang diverifikasi investor mengenai kemungkinan adanya wahana investasi yang cocok untuk investor.

c) Trend ekonomi suatu negara akan secara otomatis tersedia melalui penyediaan leading indikator

d) Sehat atau tidaknya iklim yang sehat dalam sebuah perusahaan akan tercipta apabila penyebaran kepemilikan yang terjadi secara terbuka dan atas dasar profesionalisme.

e) Terciptanya lapangan kera serta pekerjaan yang inovatif.

f) Terciptanya prospek yang tinggi pada suatu perusahaan sehingga dengan adanya pasar modal ini kesempatan yang akan di dapatkan terbuka dengan lebar.

g) Dengan keterbukaan kepemilikan maka risiko mengenai likuiditas suatu perusahaan akan menjadikan dana yang telah ditanamkan investor memiliki harapan untuk untung di masa depan, sehingga risiko ini bisa di minimalisir.

h) Tersedianya akses pengontrolan sosial yang bisa diakses siapa pun terutama investor.

i) Emiten akan memperoleh sumbangsih dana yang akan dioperasikan dalam waktu jangka panjang.

\section{Instrumen Utama Pasar Modal}

Adapun masing-masing jenis instrumen utama pada pasar modal adalah antara lain (Nasution, 2015);

1. Saham (Stock)

Merupakan surat berharga yang bersifat kepemilikan, artinya pemilik saham merupakan pemilik perusahaan. Semakin besar saham yang dimilikinya, maka semakin besar pula kekuasaannya di perusahaan tersebut. Keuntungan yang diperoleh dari saham dikenal dengan nama deviden. 15
2. Surat berharga obligasi

Merupakan instrument utang bagi perusahaan yang hendak memperoleh modal. Obligasi secara ringkasnya adalah utang tetapi dalam bentuk sekuriti. 'penerbit' obligasi adalah sipeminjam ataupun debitur. Sedangkan "pemegang" obligasi adalah pemberi pinjaman atau kreditur dan "kupon" obligasi adalah bunga pinjaman yang harus dibayar oleh debitur kepada kreditur. Dengan penerbitan obligasi ini maka dimungkinkan bagi penerbit obligasi guna memperoleh pembayaran investasi jangka panjangnya dengan sumber dana dari luar perusahaan.

Efek atau surat berharga merupakan komponen penting di pasar modal, hal ini juga di sebut dengan instrumen pasar modal (Samsul, 2006, p. 45)0), yaitu surat-surat berharga yang berupa:
a) Bukti waran
b) Saham,
c) Hak memesan efek terlebih dahulu
d) Obligasi,
e) Produk tiruan yang biasa disebut derivative.
f) Waran.
g) Reksadana
h) Bukti right

\section{Teknologi Informasi}

Teknologi menurut KBBI (kamus besar bahasa indonesia) adalah seluruh sarana untuk menyediakan barang - barang yang diperlukan bagi kelangsungan dan kenyaman hidupmanusia(KBBI, 2016). Teknologi juga dapat diartikan sebagai metode ilmiah untuk mencapai tujuan praktis atau ilmu pengetahuan terapan. Yang mana dari penguraian diatas bisa dikatakan sebagai sarana untuk memecahkan masalah mendasar dari peradaban manusia, tanpa menggunakan teknologi, maka akan banyak masalah yang tidak dapat diselesaikan dengan baik dan sempurna. Jika teknologi merupakan sarana yang memberi kemudahan atau efisiensi kepada penggunanya yang didalamnya terdapat berbagai hal yang kemungkinan dibutuhkan oleh pengguna

Informasi adalah sebuah hasil dari pengolahan beberapa data-data mentah 
yang didapatkan lalu dikemas sedemikian rupa menjadi sebuah bentuk informasi yang penting bagi penerimanya dan memiliki sebuah kegunaan sebagai dasar pengambilan keputusan oleh penggunanya yang dapat dirasakan akibatnya secara langsung kapanpun(Sutanta, 2005, p. 10).

Teknologi informasi merupakan suatu produk yang tak berwujud (intangible product), yang tidak dapat disentuh, dicium dan dirasa, namun dapat dilihat keberadaanya dalam dunia nyata(Purwanto, 2011, p. 408). Seperti halnya buku, majalah, atau koran yang mana melakukan transformasi informasi dari dan ke dunia dengan menggunakan internet dan e mail yang memproses dan menganalisa data informasi dengan microcomputer. Personal computer.Teknologi Informasi adalah suatu teknologi yang berhubungan dengan pengolahan data menjadi informasi dan proses penyaluran data/informasi tersebut dalam batas-batas ruang dan waktu. Dengan berpegang pada definisi ini, terlihat bahwa komputer hanya merupakan salah satu produk dalam domain teknologi informasi. Modem, Router, Oracle, SAP, Printer, Multimedia, Cabling System, VSAT, dan lain sebagainya, merupakan contoh dari produk-produk teknologi informasi(Indrajit, 2001, p. 11).

\section{Pengetahuan Investasi}

Edukasi investasi merupakan persepsi tentang pengetahuan atau ilmu yang telah diberikan, baik kepada mahasiswa melalui universitas atau dari pihak eksternal mengenai investasi di pasar modal (Hermanto, 2017). Pengetahuan investasi merupakan pemahaman yang harus dimiliki seseorang tentang berbagai aspek mengenai investasi, dimulai dari pengetahuan dasar penilaian investasi, tingkat risikonya dan tingkat pengembalian (return) investasi (Pajar \& Pustikaningsih, 2017). Menurut (Kusmawati, 2011), pengetahuan yang memadai tentang instrumen investasi dan cara menilai kinerja perusahaan sangat diperlukan untuk menghindari kerugian dan mendapat keuntungan yang maksimal ketika berinvestasi di pasar modal.

\section{Minat Investasi}

Minat merupakan fungsi kejiwaan atau sambutan yang sadar untuk tertarik terhadap suatu obyek baik berupa benda atau yang lain, sedangkan investasi diartikan sebagai komitmen atas sejumlah dana atau sumber daya lainnya yang dilakukan saat ini, dengan tujuan memperoleh keuntungan di masa datang(Tandelilin, 2010, p. 2).Minat investasi merupakan hasrat atau keinginan yang kuat pada seseorang untuk mempelajari segala hal yang berkaitan dengan investasi hingga pada tahap mempraktikannya, yaitu berinvestasi (Pajar $\&$ Pustikaningsih, 2017). Ciri-ciri seseorang yang berminat untuk berinvestasi dapat diketahui dari besar usaha mereka dalam mencari suatu jenis investasi dari keuntungan, kelemahan dan kinerja investasi. Kemudian, mereka melakukan investasi pada jenis investasi yang telah dipelajari atau menambah porsi atau bobot investasi yang sudah ada sebelumnya (Kusmawati, 2011).

Faktor-Faktor Yang Mempengaruhi Minat InvestasiMenurut Raditya $\mathrm{T}$ et al (2014)dalam tulisannya menjelaskan beberapa faktor-faktor yang berpengaruh terhadap minat berinvestasi,adalah antara lain:

a. Neutralinformation, adalah informasi yang berasal dari luar, memberikan informasi tambahan agar informasi yang dimiliki oleh calon investor menjadi lebih komprehensif.

b. Personalfinancialneeds, adalah informasi pribadi yang diperoleh selama investor tersebut berkecimpung dalam dunia investasi yang dapat menjadi semacam pedoman bagi investor tersebut dalam investasi berikutnya.

c. Self image/firm image coincidence, adalah informasi yang berhubungan dengan peniliaian terhadap citra perusahaan.

d. Socialrelevance, adalah informasi yang menyangkut posisi saham perusahaan di bursa, tanggung jawab perusahaan terhadap lingkungan sekitar serta area operasional perusahaan, nasional atau internasional. 
e. Classic, merupakan kemampuan investor untuk menentukan kriteria ekonomis perilaku.

f. Professional recommendation, merupakan pendapat, saran, atau rekomendasi dari pihak-pihak, saran, atau rekomendasi dari pihak-pihak, professional atau para ahli di bidang investasi.

Berdasarkan teori yang dikemukakan di atas, maka pengembangan kerangka pemikiran dapat dilihat sebagai berikut:

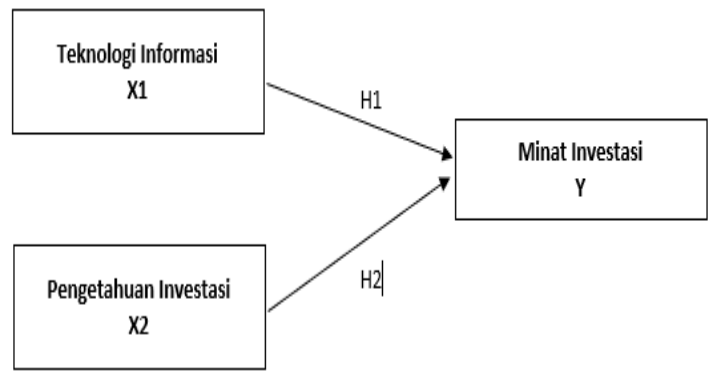

Gambar 1
Kerangka Pemikiran

Hipotesis Penelitian

H1: Terdapat pengaruh pengetahuan investasi terhadap minat investasi di pasar modal

H2: Terdapat pengaruh kemajuan teknologi terhadap minat investasi di pasar modal

\section{METODE PENELITIAN}

Penelitian ini adalah penelitian hubungan kausal dengan menggunakan data kuantitatif. Studi efek kausal adalah untuk mempelajari dampak dari satu variabel pada variabel lain, yaitu dampak kemajuan teknologi dan pengetahuan investasi terhadap minat investasi di pasar modal Indonesia. Variabel dalam penelitian ini meliputi dua variabel independen, yaitu kemajuan teknologi dan pengetahuan investasi, dan satu variabel dependen, yaitu manfaat investasi.

\section{Populasi dan Sampel Penelitian}

Populasi penelitian ini adalah para Mahasiswa Fakultas Ekonomi dan Bisnis Universitas Muhammadiyah Tangerang (yang terdiri dari mahasiswa Jurusan Manajemen S1). Sampel penelitian ini adalah mahasiswa Fakultas Ekonomi dan BisnisUniversitas Muhammadiyah Tangerang. Sampel penelitian ini diperoleh dengan menggunakan teknik Purposive sampling(Sugiyono, 2015, p. 117).

Adapun kriteria pengambilan penentuan sampel adalah:

a. Mahasiswa aktif Strata satu (S1) Fakultas Ekonomi dan Bisnis angkatan 2017 Universitas Muhammadiyah Tangerang

b. Mahasiswa Fakultas ekonomi dan bisnis yang telah lulus menempuh mata kuliah Pasar Modal

Penentuan besar sampel dalam penelitian ini ditentukan dengan rumus slovin:

$$
\mathrm{n}=\frac{N}{1+\mathrm{Ne} 2}
$$

Keterangan:

n: jumlah sampel

$\mathrm{N}$ : jumlah populasi

e: batas toleransi kesalahan (10\%)

Teknik Pengumpulan Data

Kuesioner

Menurut Sugiyono (Sugiyono, 2015, p. 142) kuesioner adalah merupakan teknik pengumpulan data yangdilakukan dengan cara memberi seperangkat pertanyaan atau pertanyaan tertulis kepada respondenuntuk dijawabnya. Untuk penyebaran kuesioner sebagai bahan penelitian diberika kepada mahasiswa Fakultas Ekonomi dan Bisnis Prodi Manajemen.Adapun bentuk skala likert menurut jonathan Sarwono (Sarwono, 2006, p. 96) sebagai berikut: 
Tabel 1 Skala Likert

\begin{tabular}{|c|l|c|}
\hline No & \multicolumn{1}{|c|}{ Keterangan } & Skor \\
\hline 1 & Sangat Setuju (SS) & 5 \\
\hline 2 & Setuju (S) & 4 \\
\hline 3 & Cukup Setuju (CS) & 3 \\
\hline 4 & Tidak Setuju (TS) & 2 \\
\hline 5 & Sangat Tidak Setuju (STS) & 1 \\
\hline
\end{tabular}

Dokumentasi

Menurut Sugiono(Sugiyono, 2015, p. 92) "pengumpulan data dengan menggunakan dokumendokumenyang telah dipublikasikan dan dikaitkan dengan penelitian". Dokumen yang digunakan dalampenelitian ini berupa foto pengisian kuesioner dan dibuktikandengan menggunakan SPSS.

\section{Studi Pustaka}

Menurut Sugiyono (Sugiyono, 2015, p. 93) "studi pustaka merupakan teknik pengumpulan data yangdigunakan untuk mendapatkan data-data yang diperlukan dalam penelitian dengan cara membacaliteratur-literaturyang

berhubungan dengan permasalahan yang diteliti”.

\section{Variabel penelitian Variabel Independen}

Menurut Indriantoro (Indriartoro \& Supomo, 1999, p. 27) "variabel Independen adalah tipe variabel yang menjelaskanatau mempengaruhi variabel yang lain, sering disebut dengan variabel yang mendahului”. Sedangkanmenurut Sunyoto (Sunyoto, 2011, p. 39) variabel yang dilambangkan dengan (X) ini memiliki pengaruh positifmaupun negatif terhadap variabel dependenya. Variabel ini sering disebut sebagai variabel stimulus,prediktor, antecedent.Adapun dalam penelitian ini yang menjadi varibael independen adalah:

Faktor-faktor

a. Kemajuan Teknologi Informasi (X1)

b. Pengetahuan Investasi (X2)

\section{Variabel Dependen}

Menurut Indriantoro (Indriartoro \& Supomo, 1999, p. 47) "variabel dependen adalah tipe variabel yang dijelaskan ataudipengaruhi oleh variabel independen dan sering disebut sebagai konsekuensi”. Adapun dalampenelitian ini yang menjadi variabel dependenya adalah minat $(\mathrm{Y})$.

\section{Metode analisis}

Metode analisis data pada penelitian ini ialah menggunakananalisis regresi linier berganda dengan alat analisis yakniSPSS (Statistical Package for Social Science) versi 20 forWindows. Namun sebelum menyebar kuesioner, terlebihdahulu menguji kuesioner melalui uji validitas dan ujireabilitas.

\section{Uji Validitas}

Uji validitas merupakan uji yang dipakai untuk mengukur valid atau sah tidaknya suatu angket (kuesioner) (Ghozali, 2016).

Uji signifikansi dapat dilakukan dengan membandingkan $\mathrm{r}$ hitung dengan $\mathrm{r}$ tabel untuk degree of freedom $(\mathrm{df})=\mathrm{n}-2$, dengan alpha $=5 \%$ atau 0,05 , dalam hal ini (n) merupakan jumlah sampel. Untuk menguji apakah maing-masing indikator dapat dikatakan valid atau sah tidaknya adalah apabila $r$ tabel lebih kecil dari $r$ hitung dan nilai $r$ hitung bernilai positif maka indikator atau pertanyaan tersebut dapat dikatakan valid (Ghozali, 2016).

\section{Uji Reabilitas}

Reliabilitas merupakan hal yang berkaitan dengan derajad stabilitas dan konsistensi data (Sugiyono, 2015: 268). Uji reliabilitas ialah alat ukur untuk mengukur angket (kuesioner) yang merupakan indikator dari variabel. Angket (kuesioner) dapat dikatakan reliabel atau handal adalah jika jawaban responden terhadap pertanyaan memiliki konsisten dan stabil dari waktu ke waktu. Untuk mengetahui apakah kuesioner dari variabel dapat dikatakan reliabel adalah dengan aplikasi SPSS menggunakan uji statistik Cronbach Alpha $(\alpha)$. Apabila nilai Cronbach Alpha lebih dari 0,70 maka 
kuesioner dikatakan reliabel (Ghozali, 2016).

Sifat dari persamaan analisis regresi linier berganda haruslah BLUE (Best Linier Unbiased Estimator), dimana dalam mengambil keputusan melalui uji $\mathrm{F}$ dan uji $\mathrm{t}$ tidak boleh bias. Untuk memperoleh hasil yang BLUE maka terlebih dahulu data harus memenuhi atau terlebih dahulu menguji data

melalui uji asumsi klasik (Sawitri, 2011).

\section{Uji Multikolinieritas}

Uji Multikolinieritas memiliki maksud sebagai menguji apakah terjadi korelasi atau hubungan antar variabel independen (bebas) dalam model regresi. Umumnya nilai cuttof yang digunakan untuk mengungkapkan terjadinya multikolinieritas adalah nilai Tolerance $<0.10$ dan nilai VIF $>$ 10. Jika tidak terjadi multikolinieritas, maka nilai nilai VIF < 10 dan Tolerance > 0.10 (Ghozali, 2016: 103-105).

\section{Uji Heterokesdastisitas}

Terdapat perbedaan variance dari suatu residual satupengamatan ke pengamatan lain dalam model regresi. Jika satu pengamatan ke pengamatan yang lain tetap, maka disebut Homokesdastisitas dan apabila berbeda disebut dengan Heterokesdastisitas. Data yang baik ialah data yang tidak mengandung heterokesdastisitas. Untuk mendeteksi tidak adanya heterokesdastisitas ialah yang pertama adalah dengan grafik scatterplot. Deteksi apabila tidak terjadi heterokesdastisitas ialah jika grafik scatterplot tidak mempunyai bentuk pola yang teratur atau jelas, dan titik-titik memencar atau menyebar baik di bawah maupun di atas angka 0 (nol) di sumbu Y. ang kedua yaitu uji glejser, bila nilai probabilitas signifikansinya di atas 0.05 , maka model regresi tidak mengalami heterokesdastisitas.

\section{Uji Normalitas}

Uji normalitas memiliki maksud sebagai menguji apakah residual atau variabel pengganggu memiliki distribusi yang normal dalam model regresi (Ghozali, 2016: 154). Data yang baik ialah data yang berdistribusi normal. Untuk mendeteksi data berdistribusi normal ialah yang pertama dengan analisis grafik histogram dan grafik normal plot. Pada grafik histogram jika data dikatakan berditribusi normal adalah dengan grafik tersebut berbentuk simetris dan tidak menceng ke kanan maupun ke kiri. Pada grafik normal plot titik-titik menyebar mendekat di sekitar garis diagonal (Ghozali, 2016). Yang kedua ialah dengan melihat nilai test statistic Kolmogorov Smirnov. Bila nilai signifikansi lebih dari 0.05 , maka data memiliki distribusi yang normal.

\section{Uji Linieritas}

Uji ini dipakai untuk memaparkan apakah spesifikasi model yang dipakai sudah betul atau tidak. Apakah fungsi yang dipakai dalam suatu studi empiris sebaiknya berbentuk linear, kuadrat, atau kubik (Ghozali, 2016, p. 159). Cara menguji apakah model regresi berbentuk linear, kuadrat, atau kubik bisa dilakukan dengan cara uji lagrange multiplier. Uji ini memiliki tujuan untuk menemukan nilai $\mathrm{c}^{2}$ hitung atau ( $\left.\mathrm{n} \quad \mathrm{x} \quad \mathrm{R}^{2}\right)$ dengan tingkat signifikansi 0.05. Apabila model linear adalah model yang benar, maka dapat diketahui dengan cara nilai $\mathrm{c}^{2}$ hitung lebih kecil dari $\mathrm{c}^{2}$ tabel (Ghozali, 2016, p. 163).

Pada dasarnya uji regresi ialah studi yang berkaitan dengan ketergantungan variabel dependen dengan satu atau lebih variabel independen, dengan maksud untuk memprediksi atau mengestimasi rata-rata populasi atau nilai rata-rata variabel dependen (terikat) berdasarkan nilai variabel independen (bebas) yang diketahui (Ghozali, 2016, p. 93).

\section{Analisis Regresi Berganda}

Analisis Regresi Linier Berganda dilakukan untuk mengetahui sejauh mana variabel pendapatan pegadaian harga emas dan tingkat inflasi yang bertindak sebagai variabel bebas mempengaruhi variabel terikat dan variabel bebasnya Fungsi atau persamaan dapat di susun antara lain:

$$
\mathrm{MI}=\beta 0+\beta 1 \mathrm{TI}+\beta 2 \mathrm{PI}+\varepsilon
$$

Keterangan: 
MI = Minat Investasi

$\mathrm{TI}=$ Kemajuan Teknologi Informasi

PI $=$ Pengetahuan Investasi

\section{Uji Signifikansi Simultan (Uji Statistik F)}

Uji F digunakan untuk menemukan apakah variabel bebas yaitu pengetahuan investasi, kebijakan modal minimal investasi dan pelatihan pasar modal secara simultan atau bersama-sama memiliki pengaruh terhadap variabel terikat yakni minat investasi. Untuk menguji hipotesismenggunakan statistik $F$,kriteria pengambilan keputusanadalah apabila nilai $\mathrm{F}$ lebih besar daripada 4 (empat) dannilai signifikansi kurang dari 0.05 maka H0 dapat ditolak danHA dapat diterima dengan arti bahwa variabel dependendipengaruhi oleh variabel independen secara bersama-samaatau simultan (Ghozali, 2016, p. 96).

\section{Uji Signifikansi Individual (Uji Statistik t)}

Pada dasarnya uji statistik $t$ ialah memaparkan seberapabesar pengaruh satu variabel bebas secara individu dalammenjelaskan variasi variabel terikat(Ghozali, 2016, p. 97). Carauntuk melihat apakah variabel terikat dipengaruhi olehvariabel bebas ialah dengan cara melihat signifikansinya.Apabila tingkat signifikansi 0.05 atau 5\%, maka nilaisignifikansi dibawah 0.05 memiliki arti bahwa variabelbebas tersebut memiliki pengaruh terhadap variabel terikat.

\section{Koefisien Determinasi}

Pada intinya Koefisien determinasi $\left(\mathrm{R}^{2}\right)$ ialah sebagai alatukur untuk mengukur seberapa besar kemampuan modeldalam menjelaskan variasi variabel dependen. Nilai koefisiendeterminasi (R2) ialah antara 0 (nol) dan 1 (satu). Nilaikoefisien determinasi yang kecil berarti kemampuan darivariabel-variabel bebas dalam menerangkan variasi variabeldependen amat terbatas. Namun nilai yang mendekati satuberarti variabel-variabel bebas memberikan hampir semuainformasi yang dibutuhkan untuk memprediksi variasivariabel dependen.

\section{HASIL DAN PEMBAHASAN}

\section{Hasil Penelitian \\ Gambaran Utama Penelitian}

Dalam penelitian ini responden yang dipilih adalah mahasiswa Fakultas Ekonomi dan Bisnis Universitas Muhammadiyah Tangerang. Populasi mahasiswa yang terdapat dalam penelitian ini berjumlah sebanyak 1200 . Sampel pada penelitian ini sebanyak 92 responden

\section{Statistik Deskriptif}

Tabel 2 Statistik Deskriptif

\begin{tabular}{|l|c|c|c|c|c|}
\hline & N & $\begin{array}{c}\text { Mini } \\
\text { mum }\end{array}$ & $\begin{array}{c}\text { Maxim } \\
\text { um }\end{array}$ & $\begin{array}{c}\text { Mea } \\
\mathrm{n}\end{array}$ & $\begin{array}{c}\text { Std. Devi } \\
\text { ation }\end{array}$ \\
\hline TI & 92 & 2,80 & 5,00 & $\begin{array}{c}3,9 \\
370\end{array}$ &, 58095 \\
\hline PI & 92 & 2,20 & 5,00 & $\begin{array}{c}3,7 \\
890\end{array}$ &, 64750 \\
\hline MI & 92 & 1,75 & 5,00 & $\begin{array}{r}3,8 \\
432\end{array}$ &, 53052 \\
\hline $\begin{array}{l}\text { Valid N } \\
\text { (listwi } \\
\text { se) }\end{array}$ & 92 & & & & \\
\hline
\end{tabular}

Sumber: data primer yang diolah, 2020

1. Kemajuan Teknologi Informasi memiliki nilai terendah sebesar 2,80 dan nilai tertingginya sebesar 5,00. dengan nilai rata-rata yang dihasilkan sebesar 3,9370 dengan standar deviasi sebesar 0,58095

2. Pengetahuan Investasi memiliki nilai terendah sebesar 2,20 dan nilai tertingginya sebesar 5,00. dengan nilai rata-rata yang dihasilkan sebesar 3,7890 dengan standar deviasi sebesar 0,64750

3. MinatInvestasi memiliki nilai terendah sebesar 1,75 dan nilai tertingginya sebesar 5,00. dengan nilai rata-rata yang dihasilkan sebesar 3,8432 dengan standar deviasi sebesar 0,53052

\section{Pembahasan}

\section{Hasil Uji Validitas}

Dari hasil pengujian uji validitas di ketahui nilai item total correlation apabila nilai tiap variabel lebih besar dari $r$ tabel maka dapat 
disimpulkan bahwa butir-butir instrumen tersebut dinyatakan valid.
Tabel 4 Hasil Analisis Regresi Linier

Berganda
Hasil Uji Reliabilitas

Berdasarkan pada tabel dapat disimpulkan bahwa data semua variabel reliabel dikarenakan nilai Cronbach Alpha > 0,60. Nilai ini menunjukkan bahwa instrumen pengukuran memberikan ketepatan dan dapat diandalkan.

\section{Hasil Uji Asumsi Klasik Uji Multikolinieritas}

Berdasarkan pada tabel dapat disimpulkan bahwa tidak ada masalah multikoliniearitas antar variabel dalam model ini, karena nilai VIF $<10$ atau nilai tolerance $>0,10$

\section{Uji Heteroskedastisitas}

Berdasarkan pada tabel di diketahui bahwa masing-masing variabel memiliki tingkat signifikan di atas 0,05. Hal ini menunjukkan tidak terjadi heteroskedastisitas.

\section{Uji Normalitas}

Tabel 3 Hasil Uji Normalitas

\begin{tabular}{|l|c|c|c|}
\hline & TI & PI & MI \\
\hline N & 92 & 92 & 92 \\
Normal & 3,9370 & 3,7890 & 3,8432 \\
MeanParameter (a, b) &, 58095 &, 64750 &, 53052 \\
Std. Deviation & & & \\
Most Extreme & .159 & .133 & .168 \\
Absolute & .129 & 106 & 105 \\
Differences & -.159 & -.133 & -.168 \\
Positive & 1.529 & 1.279 & 1.611 \\
Negative & .019 & .076 & .011 \\
Kolmogorov-Smirnov & & & \\
Z & & & \\
Asymp. Sig (2- & & & \\
tailed) & & \\
\hline
\end{tabular}

Sumber: Data Primer yang diolah 2020

Berdasarkan tabel diatas dapat disimpulkan bahwa nilai signifikan dari semua variabel data yang digunakan berdistribusi normal dikarenakan diatas nilai signifikansi Kolmogorov-Smirnov 0,05.

\section{Analisis Hasil Regresi Berganda}

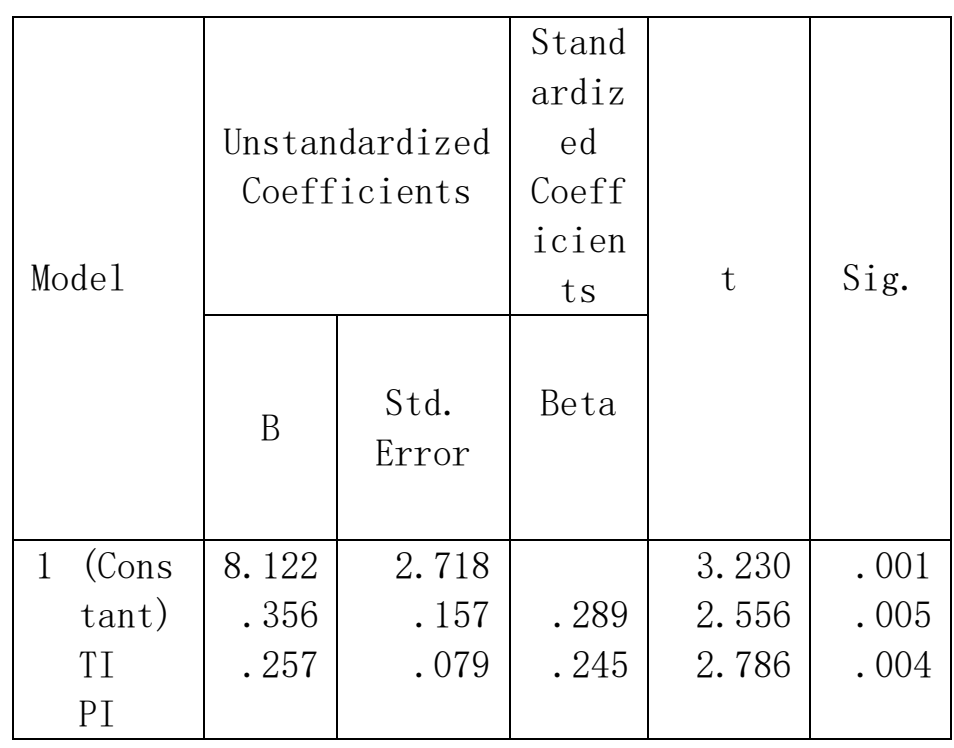

a. Dependent Variable: MI

Sumber: Data Primer yang diolah 2020 Berdasarkan tabel diatas dapat diketahui bahwa persamaan regresi untuk model penelitian ini adalah sebagai berikut: $\mathrm{Y}=8,122+0,356 \mathrm{KT}+0,257 \mathrm{PI}+\mathrm{e}$ $\mathrm{Y}=$ Minat Investasi $\mathrm{X} 1$ = Kemajuan Teknologi Informasi $\mathrm{X} 2$ = Pengetahuan Investasi $\mathrm{e}=$ Error

Hasil Uji hipotesis

Uji Signifikan Simultan (Uji Statistik F)

Tabel 5 Hasil Uji Simultan (F)

\begin{tabular}{|l|l|r|r|r|c|c|}
\hline \multicolumn{2}{|l|}{ Mode1 } & $\begin{array}{c}\text { Sum 0f } \\
\text { Squares }\end{array}$ & Df & $\begin{array}{c}\text { Mean } \\
\text { Square }\end{array}$ & F & Sig. \\
\hline \multirow{1}{*}{1} & Regression & 23.269 & 5 & 4.823 & 16.876 & .000 \\
& Residual & 26.335 & 82 & .340 & & \\
& Total & 50.609 & 93 & & & \\
\hline
\end{tabular}

Sumber: Data Primer yang diolah 2020

Berdasarkan tabel diatas dapat dilihat bahwa nilai $\mathrm{F}$ hitung adalah sebesar 16,876 dengan nilai signifikansi $\mathrm{F}$ sebesar $0,000<$ 0,05 maka hal ini menunjukkan Ho ditolak dan H1 diterima. Oleh karena itu, dapat disimpulkan bahwa variabel Teknologi Informasi (X1), Pengetahuan investasi (X2) secara simultan berpengaruh terhadap minat generasi milenial dalam berinvestasi. 
Uji Koefisien Determinasi (adjusted $\left.\mathbf{R}^{2}\right)$

Tabel 6 Hasil uji Koefisien Determinasi

\begin{tabular}{|r|c|c|c|c|}
\hline Mode1 & $\mathrm{R}$ & $\mathrm{R}$ & $\begin{array}{c}\text { Adjusted } \\
\text { Square }\end{array}$ & $\begin{array}{c}\text { Std. } \\
\text { Error of } \\
\text { the } \\
\text { estimate }\end{array}$ \\
\hline 1 & .650 & .422 & .415 & .55643 \\
\hline
\end{tabular}

Sumber: Data Primer yang diolah 2020

Berdasarkan tabel di atas, menunjukkan bahwa hasil $\mathrm{R}$ Square yang disesuaikan adalah 0,415 yaitu $41,5 \%$. Variabel dependen minat Investasi (Y) dapat dijelaskan oleh variabel Teknologi Informasi (X1), Pengetahuan Investasi (X2). Sedangkan $58.5 \%$ dapat dijelaskan variabel lain yang tidak diolah oleh peneliti.

\section{Tabel 7 Uji Parsial (uji t)}

\begin{tabular}{|c|c|c|c|c|c|}
\hline \multirow[t]{2}{*}{ Mode1 } & \multicolumn{2}{|c|}{$\begin{array}{l}\text { Unstandardiz } \\
\text { ed } \\
\text { Coefficients }\end{array}$} & $\begin{array}{l}\text { Stan } \\
\text { dard } \\
\text { ized } \\
\text { Coef } \\
\text { fici }\end{array}$ & \multirow[t]{2}{*}{ t } & \multirow[t]{2}{*}{ Sig. } \\
\hline & B & $\begin{array}{l}\text { Std. } \\
\text { Erro } \\
\text { r }\end{array}$ & Beta & & \\
\hline $1 \begin{array}{c}\text { (Cons } \\
\text { tant) }\end{array}$ & $\begin{array}{r}8.122 \\
.356\end{array}$ & $\begin{array}{r}2.71 \\
8\end{array}$ & .289 & $\begin{array}{l}3.230 \\
2.556\end{array}$ & $\begin{array}{l}.001 \\
.005\end{array}$ \\
\hline $\begin{array}{l}\text { TI } \\
\text { PI }\end{array}$ & .257 & $\begin{array}{l}.157 \\
.079\end{array}$ & .245 & 2. 786 & .004 \\
\hline
\end{tabular}

Sumber: Data Primer yang diolah 2020

\section{Hipotesis pertama Pengaruh teknologi informasi terhadap minat berinvestasi}

Hasil pengujian menunjukan bahwa Teknologi Informasi berpengaruh terhadap Minat Investasi dengan nilai Sig sebesar $0,000(0,001<0,05)$ mengindikasikan bahwa H1 diterima bahwa variabel teknologi informasi berpengaruh signifikan positif terhadap variabel minat.Pertimbangan dampak dari teknologi atas proses pembelian dan penjualan sekuritas ialah teknologi sebagai acuan yang dapat memberikan keunggulan signifikan, agar tetap kompetitif dalam ekonomi yang digerakkan oleh teknologi, teknologi juga merupakan salah satu faktor yang mendukung proses permainan saham / sekuritas sehingga dengan adanya teknologi semakin memberi kemudahan dalam melakukan proses investasi.Menurut Sukirno faktor-faktor yang dapat menjadi penentu tingkat minat investasi salah satunya Teknologi Informasi(Sukirno, 2011, p. 122).

Hipotesis kedua Pengaruh pengetahuan investasi terhadap minat berinvestasi

Hasil pengujian menunjukan bahwa pengetahuan Investasi berpengaruh terhadap Minat Investasi dengan nilai $\mathrm{t}$ 2,786 dengan nilai Sig sebesar 0,000 $(0,004<0,05)$ mengindikasikan bahwa $\mathrm{H} 2$ diterima. variabel pengetahuaninvestasi pada penelitian ini berpengaruh signifikan positif terhadap variabel minat.Keputusandalam mengambil investasi sesorang dilatarbelakangi oleh pemahaman akan investasi. Menurut Notoatmodjo Pengetahuan atau kognitif merupakan domain yang sangat penting dalam membentuk tindakan seseorang (overt behaviour)(Notoatmodjo, 2012, p. 15). Pengetahuan yang memadai akan suatu hal dapat memberikan motivasi seseorang untuk mengambil keputusan atau melakukan suatu tindakan. Untuk melakukan investasi di pasar modal diperlukan pengetahuan. Salah satu faktor yang Mempengaruhi Pengetahuan seseorang yaitu pengalaman dan pendidikan

\section{SIMPULAN}

Penelitian ini dilakukan dengan tujuan untuk menganalisis pengaruh teknologi informasi dan pengetahuan investasi terhadap minat berinvestasi di pasar modal. Sampel dalam penelitian ini adalah 92 responden yang terpilih dan dilakukan penyebaran kuesioner. Metode analisi yang digunakan adalah regresi linear berganda dengan aplikasi SPSS. berdasarkan hasil uji pada bab sebelumnya maka disimpulkan sebagai berikut:

1. Hasil pengjian secara secara simultan menunjukan bahwaTeknologi Informasi dan Pengetahuan Investasi 
berpengaruh terhadap minat berinvestasi.

2. Hasil pengujian menunjukan bahwa secara parsial teknologi informasi berpengaruh terhadap minat investasi.

3. Hasil pengujian menunjukan bahwa Pengetahuan Investasi secara parsial berpengaruh terhadap Minat Berinvestasi

\section{DAFTAR PUSTAKA}

Ajzen, I. (1991). The theory of planned behavior. Organizational Behavior and Human Decision Processes. https://doi.org/10.1016/07495978(91)90020-T

Anoraga. (2001). Rumus menghitung harga saham gabungan. In Pengantar Pasar Modal. Edisi Revisi. Cetakan III.

Darmadji, T., \& Fakhruddin, H. M. (2012). Pasar Modal Di Indonesia. In Salemba Empat.

Ghozali, I. (2016). Aplikasi Analisis Multivariate dengan Program IBM SPSS 23. (Edisi 8). Semarang: Badan Penerbit Universitas Diponegoro.

Halim, A. (2005). Analisis investasi. Jakarta: Salemba Empat.

Hermanto. (2017). Perilaku Mahasiswa Ekonomi Di Universitas Esa Unggul. Jurnal Ekonomi.

Indrajit, R. E. (2001). Manajemen sistem informasi dan teknologi informasi. PT Elek Media Komputindo, Jakarta.

Indriartoro, N., \& Supomo, B. (1999). Metodologi Penelitian Untuk Akuntansi Dan Manajemen. In BPFE.

KBBI. (2016). Kamus Besar Bahasa Indonesia ( KBBI ). In Kementerian Pendidikan dan Budaya.

Khotimah, H., Warsini, S., \& Nuraeni, Y. (2011). Pengaruh Sosialisasi dan Pengetahuan terhadap Minat Investor pada Efek Syariah di Pasar Modal. Jurnal Account.

Kusmawati. (2011). Pengaruh Motivasi Terhadap Minat Berinvestasi Di Pasar Modal Dengan Pemahaman Investasi Dan Usia. Jurnal Ekonomi Dan Informasi Akuntansi (JENIUS).

Malik, A. D. (2017). Analisa Faktor Faktor Yang Mempengaruhi Minat Masyarakat Berinvestasi Di Pasar Modal Syariah Melalui Bursa Galeri Investasi UISI. Jurnal Ekonomi Dan Bisnis Islam (Journal of Islamic Economics and Business).

https://doi.org/10.20473/jebis.v3i1. 4693

Merawati, L. K., \& Putra, I. P. M. J. S. (2015). Kemampuan Pelatihan Pasar Modal Memoderasi. Jurnal Ilmiah Akuntansi Dan Bisnis.

Munirah Ira, Nurkholis, \& Sutrisno. (2012). Sutrisno. Manajemen Keuangan: Teori Konsep \& Aplikasi.

Nasution, Y. S. J. (2015). Peranan Pasar Modal Dalam Perekonomian Negara. HUMAN FALAH: Jurnal Ekonomi Dan Bisnis Islam.

Nisa, A., \& Zulaika, L. (2017). Pengaruh Pemahaman Investasi, Modal Minimal Investasi Dan Motivasi Terhadap Minat Mahasiswa Berinvestasi Di Pasar Modal. Jurnal PETA.

Notoatmodjo, S. (2012). Promosi Kesehatan \& Ilmu Perilaku. In Jakarta: Rineka Cipta.

Pajar, R. C., \& Pustikaningsih, A. (2017). Pengaruh motivasi investasi dan pengetahuan investasi terhadap minat investasi di pasar modal pada mahasiswa fe uny. Profita.

Purwanto, Y. (2011). Berita Ilmu Pengetahuan dan Teknologi. 
Jurnal Sosioteknologi.

Raditya T, D., Budiartha, I. K., \& Suardikha, I. M. S. (2014). Pengaruh Modal Investasi Minimal Di Bni Sekuritas, Return Dan Persepsi Terhadap Risiko Pada Minat Investasi Mahasiswa, Dengan Penghasilan Sebagai Variabel Moderasi. E-Jurnal Ekonomi Dan Bisnis Universitas Udayana 3.7.

Samsul, M. (2006). Pasar modal dan manajemen portofolio. Jakarta: Erlangga. https://doi.org/10.22236/agregat

Sarwono, J. (2006). Metode Penelitan Kuntitatif dan Kualitatif. Buku Metode Penelitian Kuantitatif Dan Kualitatif.

Sawitri, D. P. P. (2011). Dampak Rasio Keuangan Terhadap Kebijakan Deviden. Bisnis Dan Manajemen. https://doi.org/10.1017/CBO97811 07415324.004

Sugiyono. (2015). Metode Penelitian. Metode Penelitian.

Sukirno, S. (2011). Teori Pengantar Ekonomi Makro. In Jakarta.

Sunyoto, D. (2011). Analisis Regresi dan Uji Hipotesis. In Buku seru.

Sutanta, E. (2005). Dukungan Sistem Informasi Manajamen (SIM) Dalam Kegiatan Manajemen. Jurnal MANAJERIAL, STMIK AMIKOM Yogyakarta, ISSN: 0216-3705.

Tandelilin, E. (2010). Portofolio dan Investasi. In Kanisius.
Tandio, T., \& Widanaputra, A. (2016). Pengaruh Pelatihan Pasar Modal, Return, Persepsi Risiko, Gender, Dan Kemajuan Teknologi Pada Minat Investasi Mahasiswa. EJurnal Akuntansi.

Van Rooij, M. C. J., Lusardi, A., \& Alessie, R. J. M. (2011). Financial literacy and retirement planning in the Netherlands. Journal of Economic Psychology. https://doi.org/10.1016/j.joep.2011. 02.004

van Rooij, M., Lusardi, A., \& Alessie, R. (2011). Financial literacy and stock market participation. Journal of Financial Economics. https://doi.org/10.1016/j.jfineco.20 11.03.006

www.economy.okezone.com/diakses taggal 23 juni 2020 